\title{
A Practioner Guide To The Unfair Competition Law In Jordan
}

\author{
Haitham A. Haloush* \\ Department of Accounting and Commercial Law, Faculty of Economics and Administrative Sciences, The Hashemite University, \\ Zarqa 13115, Jordan
}

\begin{abstract}
Until the year 2000, there was no specific statute enacted in Jordan that regulates unfair competition. In the year 2000, the Jordanian Unfair Competition Law No. 15 of 2000 was enacted. The Law deals with the issue of unfair competition in a very generic way. In addition to the Jordanian Unfair Competition Law, the principal statutory source of protection is implemented through the general rules and principles of civil law, particularly, tort law and injurious acts. Although the Jordanian Unfair Competition Law purports to implement a general legal regime on unfair competition, it includes very little in terms of substantive or procedural protection of unfair competition. Presently, the Jordanian legal system provides only very limited protection which is not adequate to accommodate unfair competition cases. Therefore, statutory changes are needed.
\end{abstract}

\subsection{INTRODUCTION}

Little is known about Arab and Islamic law, including Jordanian law. It is rather a realistic approach that businessmen should know about unfair competition law of other countries and that they know about effectiveness, fairness, speed and cost of judicial procedures abroad (Carroll 2001). As far as the author is aware, the issue of unfair competition in Arab countries, including Jordan, has not been researched before from technical and legal standpoints since unfair competition is a newly developed area. This Article represents a first attempt to examine the issues arising in this difficult and important subject. Therefore, this article will examine the suitability of the Jordanian legal system in providing sufficient protection of unfair competition. The article concludes that there are serious obstacles in terms of substantive and procedural protection of unfair competition in Jordan and provides some recommendations in this regard.

In order to examine this issue, this article is divided into two sections. First, the scope of application of unfair competition under the Jordanian law. Second, the legal Protection of unfair competition in Jordan. Finally, the conclusion of the article will relate the finding to each other in a coherent way and suggests practical solutions to some pitfalls of the current law.

Merchants are indoctrinated for competition which is essential and perhaps inevitable in all commercial fields in order to attract customers. However, it has been argued that although every competitor who wins customers from another justifiably damages the business of the losing competitor, that damage is merely damnum absque injuria. (Knight 1978) In other words, the justified diminution, injury, even

*Address correspondence to this author at the Department of Accounting and Commercial Law, Faculty of Economics and Administrative Sciences, The Hashemite University, Zarqa 13115, Jordan; Tel: + (5) 390-3333-4459; Mobile: + 0795162296; Fax: + (5) 390-3344;

E-mail: h_haloush@hotmail.com; haithamhaloush@hotmail.com the destruction, of the business of a competitor is not an injury, in the legal sense, and will warrant no relief, because it is the effect of the exercise of an unquestioned right (callman 1994) Thus, legal framework that allows fair competition to develop and flourish is needed for both traders and customers (Muhriz 1994). Until the year 2000, there was no specific statute enacted in Jordan that regulates unfair competition. In the year 2000, the Jordanian Unfair Competition Law No. 15 of 2000 (hereinafter referred to as ("JUCL") was enacted. (The Jordanian Unfair Competition Law No. 15 of the year 2000. The law has been published in the Jordanian Official Gazette No. 4423 dated 2/4/2000 at p.1316). Although the JUCL purports to implement a general legal regime on unfair competition, it includes very little in terms of substantive or procedural protection of unfair competition. The Law deals with the issue of unfair competition in a very generic way. There is an article discusses broadly the actions constituting unfair competition. Another article describes generally litigation procedures. The remaining few articles discusses trade secrets and intellectual property licensing in a rather generic way. The law includes only 8 articles. In addition to the JUCL, the principal statutory source of protection is implemented through the general rules and principles of civil law, particularly, tort law and injurious acts.

The case law, in this area, is rather non-existent. This reflects, to a large extent, the noticeable absence of litigation in Jordan with regards to unfair competition. For example, trademarks infringement cases which have been dealt with specifically under the Jordanian trademarks Law No. 33 of the year 1999, can be categorized under unfair competition. For some unknown reasons, however, disputants in Jordan are prone to resort to specific laws that address the issue at hand, i.e., trademarks law, rather than unfair competition law. This might be attributed to the educational and cultural gap in the field of unfair competition. In a leading case in trademarks infringement in Jordan, the claimant, a foreign company, filed a lawsuit against another local company, which was engaged in the manufacturing of products which 
were identical to those of the claimant's thereby constituting trademark infringement, and impliedly, unfair competition. The claimant requested the seizure of the products and paying compensation according to the provisions of the Jordanian Trademarks Law. After the Court has examined the case, it was proved that the local company sold products bearing trademarks imitating the claimant's trademarks and illegally used the claimant's registered trademark to mislead customers and sold the imitated products to the public with a noticeable difference in price and quality in addition to the different origin of the products. Therefore, the court has decided to charge the infringer company to pay 1,100 Jordanian Dinars (1 Dinar is equivalent to 71 American Cents) as a compensation along with the official fees, expenses, and JD70 as the lawyer's remunerations. (The Jordanian Court of Cessation, Case No.112/24, Journal of Jordanian Bar Association 2431 (2004). Surprisingly, there was no reference whatsoever to unfair competition law.

\subsection{THE SCOPE OF APPLICATION OF UNFAIR COMPETITION UNDER THE JORDANIAN LAW}

Competition law in the broad sense comprises two branches: antitrust law which introduces a prohibition of abuse of economic dominance, i.e. the law relating to restrictive practices, monopolies and mergers, and the law of unfair competition which relates to a wide range of trade practices, e.g., deceptive advertising, trade marks, trade names and trade secrets protection, counterfeit of non-protected products, concepts and configurations, interference with contractual relationships of all kinds (distribution systems, client or labor relations), disparagement of competitors, etc. (The Jordanian Antitrust Law No. 49 of the year 2002. The law has been published in the Jordanian Official Gazette No. 4560 dated $15 / 8 / 2002$ at p.3836. This Law has made Jordan the first Arab country in the middle east with Antitrust legislation in place). There is a close link between the two parts of competition law. Although they are the object of two different Acts with their own substantive rules and procedures, some scholars argue that restrictive practices can be qualified as acts of unfair competition (Hanns 2005). However, critical analyses of the inter-relationship between antitrust law and unfair competition law and various forms of unfair trade practices are beyond the limits of this article. So that it was decided not to examine these issues here. This is not because such issues are not valid and important. Rather, it presents legal questions which are fundamentally different from legal questions in the JUCL. However, it might be useful to provide brief analyses of those issues where appropriate.

The concept of unfair competition is at best amorphous; its definition has traditionally been a subject of lengthy debate (Callman 1994). It is impossible to frame definitions which embrace all unfair practices. There is no limit to human inventiveness in this field. Even if all known unfair practices were specifically defined and prohibited, it would be at once necessary to begin over again (Knight 1978)

Broadly speaking, unfair competition refers to the passing-off of one's goods, products or services as the goods, products or services of another competitor. Such practice, which contradicts laws, ultimately results in creating uncertainty with regards to a competitor's goods product or services (Qalioubi 2005)
Article 10bis of Paris Convention for the Protection of Industrial Property of the year 1883 and its amendments defines unfair competition as an act which is contrary to honest business practices. The Article reads as follows:

(1) The countries of the Union are bound to assure to nationals of such countries effective protection against unfair competition. (2) Any act of competition contrary to honest practices in industrial or commercial matters constitutes an act of unfair competition. (3) The following in particular shall be prohibited: (i) all acts of such a nature as to create confusion by any means whatever with the establishment, the goods, or the industrial or commercial activities, of a competitor; (ii) false allegations in the course of trade of such a nature as to discredit the establishment, the goods, or the industrial or commercial activities, of a competitor; (iii) indications or allegations the use of which in the course of trade is liable to mislead the public as to the nature, the manufacturing process, the characteristics, the suitability for their purpose, or the quantity, of the goods. (Article 10bis of Paris Convention for the Protection of Industrial Property of the year 1883 and its amendments (official English Text), available online at http://www.wipo.int/treaties/en/ip/paris/ trtdocs_wo020.html\#P213_35515, last visited on the $1^{\text {st }}$ of November 2008).

The prohibition of unfair competition, as defined by the Paris Convention, was a kind of extension of the protection of industrial property. Not only patents, trademarks, designs or models and copyright belonging to a trader's business should be protected against passing off, but also his business name or goodwill, elements which are not specifically protected by an absolute right. It has been argued that unfair competition, as a "plastic" term, enjoys significant flexibility, as its meaning continues to derive more from underlying rationale, rather than any clear lexical boundaries. Drafters of unfair competition laws have in particular been hesitant to "define", and thereby limit, this elastic legal area (Callman 1994). It has been said also that such formulations do not purport to define unfair competition; rather, they reflect the principle that competition is to be denounced as unfair when inconsistent with current standards of honest commercial practice. More particularly, it has been indicated that unfair competition cannot be narrowly defined (Knight 1978).

In Jordan, in order to improve the enforceability of the prohibition of unfair competition contained in the Paris Convention, the JUCL was introduced. (Jordan has acceded to Paris convention and the Convention entered into force on July 1972. It is worth noting that Article 2(1) of TRIPS agreement has adopted Article 10bis of Paris Convention. Article 2 of the JUCL is similar to Article 10bis of Paris Convention). Article 2 of the JUCL states that any competition contradictory to the honest practices in the commercial and industrial activities shall be deemed one of the unfair competition acts, and, particularly, the activities that may by nature cause confusion with entity, products or commercial or industrial activities of one of competitors, untrue assumptions in practicing trade, whereby causing deprivation of trust from one of the competitors' entity, products or industrial or commercial activities, the data or assumptions which use in commerce may mislead public in respect to the product's nature, methods of manufacturing, properties, amounts, and availability for use, and finally, any 
practice that reduce the product reputation, cause confusion in respect to the product general shape or presentation, or mislead the public on declaring the product price or the method of counting thereof. (Article 2 of JUCL).

Upon reading Article 2 of the JUCL, one can notice that the Jordanian law does not include a general statutory definition of unfair competition. The law merely provides generic examples of unfair competition in a non-exhaustive manner. This situation may be used by the judiciary to interpret liberally the concept of unfair competition to encompass any conduct which is contrary to commercial usages governing industry and trade, such as, the prohibition of blackening or hindering a competitor, exploiting a competitor, etc. In fact, JUCL had its origins in protectionist notions of honest trade, and, therefore, the general clause covers any infringement in the conduct of business. The determination of whether a particular business practice is unfair necessarily involves an examination of its impact on its alleged victim, balanced against the reasons, justifications and motives of the alleged wrongdoer. In brief, there must be a balance between the utility of the wrongdoer's conduct against the gravity of the harm to the injured (Arkin 2005). For example, in trademarks infringement, which is an apparent example of unfair competition, the Jordanian cassation court grants judges wide discretionary power in deciding whether an infringing trademark is similar or confusingly similar to a legally protected trademark. (The Jordanian Court of Cessation, Case No.21/88, Journal of Jordanian Bar Association 2552 (2007). See also, Article 7 of the Jordanian Trademarks Law No.33 of the year 1999 and its amendments). Apparently, the Jordanian law recognizes that it is impossible to set out a definitive list of forms of unfair competition, and, therefore, it has justifiably been said that:

It would be impossible to draft in advance detailed plans and specifications of all acts and conduct to be prohibited ..., since unfair or fraudulent business practices may run the gamut of human ingenuity and chicanery (Deutch 2004).

Legal certainty, however, could only be ensured by adhering closely to statutory provisions and refraining from extensive judicial developments that might lead to an obsolete law. This approach raises the basic dilemma as to the degree to which judicial activism is desirable. This issue is the subject of persisting controversy in Jordan. For example, the Jordanian legislator does not differentiate between unfair competition and illegal or unlawful competition. Illegal competition might be prescribed by law as being illegal or contractually agreed upon between parties as being illegal. As for the former, i.e., prescribed by law as being illegal, Article 14 of the Jordanian Commercial Code states that civil servants and Judges are strictly prohibited from practicing trade. (Article 14 of the Jordanian Commercial Code No. 12 of the year 1966. The law has been published in the Jordanian Official Gazette No. 1910 dated 30/3/1966 at p.472). Also, Article 8(c) of the Jordanian Bar Association law, and Article 7(c) of the Jordanian Medical Council Law state respectively that practicing law or medicine in Jordan is conditioned on having a Bachelor degree in Law or a Bachelor degree in medicine. (Article 8(c) of the Jordanian Bar Association Law No. 51 of the year 1985. The law has been published in the Jordanian Official Gazette No. 3340 dated
17/9/1985 at p.1327. See also, Article 7(c)of the Jordanian Medical Council Law No. 81 of the year 1972. The law has been published in the Jordanian Official Gazette No. 2384 dated 5/10/1972 at p.1859).

Besides, Article 21 of the Jordanian Patent Law states that a patent shall grant its owner the right to prevent any person who hasn't obtained the owner's authorization from making, exploiting, using, offering for sale, selling or importing that product. (Article 21(a)(1) of the Jordanian Patent Law No.32 of the year 1999 and its amendments).

Similarly, Article 21(a)(1) of the Jordanian Companies Act states that:

A partner in a general partnership or the authorized person in managing it, whether a partner or other, shall not be permitted to undertake any of the following actions without obtaining the prior written approval of the remaining partners or all of them, as the case may be: a) To enter into any undertaking with the Company to realize any business, whatever its nature, on its behalf. b) To enter into any undertaking or agreement with any person if the subject-matter of the undertaking or the agreement falls within the objectives and activities of the Company. c) To engage in any business or activity which competes with the Company, whether he carried out the said business or activity for his own benefit or for the benefit of others. d) To participate in any other company which carries out businesses similar or analogous to those of the Partnership or to assume the responsibility of managing such companies. (Article 21 of the Jordanian Companies Act and its amendments No. 22 of the year 1997. The law has been published in the Jordanian Official Gazette No. 4204 dated 15/5/1997 at p.2038).

Article 63 of the Jordanian Companies Act states also that the manager of a Limited Liability Company, whether a sole manager or a manager appointed by the Management Committee, and any member of the Management Committee shall be prohibited from assuming any position in any other company with objectives similar to or competitive with the Company business and from realizing any work similar to the Company business, whether for his own account or for the account of others, with or without payment, or to participate in managing another company having objectives similar to or competitive with those of the Company except with approval of the General Assembly by a majority vote of not less than $75 \%$ of the shares forming the Company capital. (Ibid. Article 63).

As for the latter, i.e., contractually agreed upon between parties as being illegal, Article 685 of the Jordanian Civil code states that in a sale or lease contract, the seller or the owner of the leased property is obliged to restrain from any obstruction that may result in the deprivation of the buyer or the lessee from benefiting from the sold or leased property in accordance with the contract, in which case, there may be rescission or compensation for the damages. (Article 685 of The Jordanian Civil Code No.43 of the year 1976 which comes into effect on the $1^{\text {st }}$ of January, 1977).

So, if there was an agreement between parties whereby, say, the seller agree not to practice similar trade within certain geographical boundaries or certain time limitations, then, according to the Jordanian Civil Code, such practice 
shall be considered as illegal competition rather than unfair competition.

Similarly, traders may enter into agreements to restrict freedom of trade among themselves within certain geographical boundaries or certain time limitations or price and products restrictions. Such practices will inevitably affect the demand and supply rule in the market, and, impliedly, constitutes an unfair competition practice (Melhem 1995). Therefore, Article 5(a) of the Jordanian Antitrust Law has prohibited those practices as illegal competition rather than unfair competition. (Article 5(a) of the Jordanian Antitrust Law No. 49 of the year 2002. The Article states that: "Practices, alliances and agreements, explicit or implicit, that prejudice, contravene, limit or prevent competition, shall be prohibited, especially those whose subject or aim is to: Fix the prices of products, services or conditions of sale, and the like. Fix quantities of production or service provision. Share the market on the basis of geographical regions or quantities of sales or purchases or customers or any other basis that negatively affects competition. Set barriers to entry of Enterprises into the market or eliminate them there from. Collusion in tenders or bids, whether in overbidding or underbidding, but it shall not be considered collusive to submit joint offers in which the parties announce such joint offer, and without the goal of such joint bidding being to prevent competition in any way").

In addition, Article 818 of the Jordanian Civil code states that, in a contract of employment, the two parties may agree that the worker shall not compete with the employer or participate in competitive work after the termination of the contract. But the agreement shall not be acceptable unless it is restricted in the time, place and type of work to the extent necessary for the protection of the legitimate interests of the employer. (Article 818 of The Jordanian Civil Code No.43 of the year 1976. See also, Article 19(b) of the Jordanian Employment Law No. 60 of the year 2002. The law has been published in the Jordanian Official Gazette No. 4576 dated 10/10/2002 at p.4915).

Normally, workers gain administrative experience, trade knowledge, trade secrets, identities of suppliers or customers, etc., which might be used in the future for their own benefit. Consequently, according to the Jordanian Civil Code, such practice shall be considered as illegal competition rather than unfair competition.

The following section of this article identify the factors that must be proved in a proceeding in order to determine if certain conduct must be considered an unfair competition conduct and what are the legal mechanisms that the JUCL establishes for a person who is injured by such conduct. The following analysis is essential to a discussion of the issues and responses that are emerging in the field of unfair competition in Jordan.

\subsection{LEGAL PROTECTION OF UNFAIR COMPETI- TION IN JORDAN}

Legal protection is granted as a remedy against specific forms of misappropriation of another enterprise's accomplishment in competition. In that respect, it is not the investments made for or the efforts spent on such accomplishments that determine protection, but the conduct of the defendant and the manner of misappropriation. These must show the hallmark of unfairness. There must also be additional elements of unfairness, such as a risk of deception of customers in case the accomplishment in question is generally attributed to a specific enterprise, or a risk of reputation damage, or some breach of confidence and so on (Hanns 2005).

Despite the fact that unfair competition may cause irreparable damages, the JUCL does not contain legal provisions that impose criminal penalties on infringers of fair competition. Therefore, reference should be paid to the related provisions of the Jordanian Criminal Code which includes an extremely broad provision imposing sanctions on unfair competition. For example, Article 435 of the Jordanian Penal Law No. 33 of the Year 2002 states that using deceptive means and measures to increase or decrease the values of goods or services in the market, which might affect the supply and demand rule, or induce others to do same, shall be imprisoned up to 1 year and shall pay fine up to 100 Jordanian Dinars. The penalty shall be doubled if the abovementioned practice is related to essentially vital goods or services. (Article 435 of the Jordanian Penal Law No. 33 of the Year 2002. The law has been published in the Jordanian Official Gazette No. 4524 dated 31/12/2001 at p.6026).

As far as the author is aware, this provision had never been applied effectively in Jordan.

According to Article 3 (a) of the JUCL, any concerned party may claim compensation for the damages caused to him as a result of any unfair competition. (Article 3 (a) of JUCL. In this regard, Article 288(b) of the Jordanian Civil Code No.43 of the year 1976 states that: " No person shall be liable for the act of another and yet the Court may on the application of the injured person, and if it finds it justifiable, hold liable for the awarded damages any person who had actual power to supervise and direct the person who had inflicted the damage even though he himself had no free choice if the injurious act was committed by the supervised person while or because of performing the duties of his post.")

The action can be brought by every party, whether natural or juristic person, who has a direct and individual interest, e.g., a competitor or an individual customer, the Minister of Trade and Industry, trade associations with legal personality, and customer organizations represented in the Jordanian Customer Council (Saleh 1999).

Although the JUCL is directed towards unfair business competition, it does not restrict its application only to situations in which business competitors are harmed. Indeed, the goal of the Act is much broader and is intended to address the general societal harm that results when enterprises act illegally. Especially, if evidence demonstrates that the public is likely to be misled by an unfair competition that is all that needs to be proven. It is not even required to prove that any member of the public sustained damages or that the defendant intended to deceive anyone. However, as mentioned before, the JUCL includes very little in terms of substantive or procedural protection of unfair competition. Accordingly, reference should be paid to other statutory sources of protection which are implemented through the general rules and principles of civil law.

Some jurists argue that unfair competition action shall be based on the concept of abuse of right. At a normative level, 
fair competition is sought to be as a granted right for traders according to commercial customs whereby unfair competition is an abuse of such right (Sanhuri 1952). Those scholars regard the exercise of free competition by the entrepreneur as a liberty or right, though not absolute and unqualified. Commercial conduct that is contrary to trade usages is condemned as an abuse of the right to compete freely. Such doctrine provides that whoever abuses the exercise of his legal rights should be held liable for the consequences of that abuse (Knight 1978).

According to the Jordanian law, Articles 66(1) of the Jordanian Civil Code states that a right holder should enjoy his right without trespassing on others' rights. Apparently, trespassing is deemed to be abuse of right. (Article 66(1) of The Jordanian Civil Code No.43 of the year 1976. The Article provides that: "Liability for damage shall be due from the person who exercises his right unlawfully").

In addition, Article 66(2) stipulates that an intention of creating detrimental effects on others should be evident. This condition can be deducted from the intention of the wrongdoer whether it was beneficial for him or detrimental for others and this matter is left to the trial judge to decide upon it. An objective rather than subjective test would be deployed here in order to determine the necessity or lack of necessity of one's performance of his right. (Ibid. Article 66(2). The Article provides that: "The exercise of the right shall be unlawful: a. if there is intent to aggress. b. If the interest to be achieved from the act is unlawful. c. If the benefit there from is disproportionate with the damage inflicted on others. d. If it exceeds custom and usage").

The argument that was put forward in order to base unfair competition on the concept of abuse of right is flawed, to say the least. This is due to the fact that in marked contrast with the statutory definition of abuse of right, the existence of bad faith is irrelevant in determining upon unfair competition whereby the proof of damages by the competitors, who were put at a competitive disadvantage, is sufficient. Indeed, the likelihood of confusion rather than any element of wrongful intent to deceive has become the standard and norm in an unfair competition dispute. This is not to say that negligence and intent are not relevant; rather they have been relegated to minor roles, becoming important only in the judgment and the award of damages (Knight 1978).

Also, the statutory definition of abuse of right implies that determination upon such practice shall be according to the materialization of a targeted object while unfair competition implies that determination upon such practice shall be according to the tools and vehicles used to achieve a targeted object.

Other Jurists argue that unfair competition action shall be based on the infringement of one's real right (Aukaili 2007). Real right is an authority given to a person over a thing, whether this thing is movable or immovable, tangible or intangible. It is a right recognized and enforced by law. Such right gives the owner the faculty to use, exploit and dispose of the thing. The owner, in this respect, can stop interference of any other person as he possesses a direct authority over the right itself. (Article 69 of The Jordanian Civil Code No.43 of the year 1976. The Article reads as follows: "The real right is a direct power over a certain thing granted by the law to a certain person").

However, the argument that was put forward in order to relate unfair competition to infringement of real right is similarly flawed. This is due to the fact that although practicing trade consists of a gathering of various elements, including attracting customers, which is of vital importance in conducting trade, it is not realistic to consider that a trader has a real right over his customers. Apparently, a trader can never prevent his customers from dealing with other traders.

Also, such assumption implies that an owner of a business concern is entitled to enforce his real right and can solely stop interference of any other person as he possesses a direct authority over the right itself. However, if the granted right of exploitation to the owner has been assigned to others, i.e., lease of business concern, then it will be questionable whether a tenant would be entitled for such protection (Abu-Awad 2007).

Having said that, the author believes that the resort to the generic principles of tort law and injurious acts to deal with unfair competition is more adequate. Historically, the law of unfair competition evolved in the general field of torts. It was concerned primarily with wrongful conduct in commercial enterprises that resulted in business loss to another, ordinarily by the use of unfair means in drawing away customers from a competitor. With passage of time and accompanying epochal changes in industrial and economic conditions, the legal concept of unfair competition broadened appreciably (Arkin 2005).

Apparently, there are no specific tort rules applicable to unfair competition under the Jordanian law. However, the Civil Code includes broad provisions that apply in principle to all types of illegal conduct that causes damage to another person or to his property, and that could therefore be considered applicable to the damages caused by an unfair competition. Indeed, there is a valid justification for circumventing unfair competition legislation by means of the flexible mechanism of the tort law and injurious acts (Sease 1994).

Under the Jordanian legal system, the general rules and principles of tort law and injurious acts are included in chapter 3 of the Jordanian Civil Code. Generally speaking, the Jordanian legislature states that every injurious act shall render the person who commits it liable for damages even if he is a non-discerning person. In this case, any compensation to damages shall not be confined only to the actual losses that have been encountered by the injured person, in addition, compensation shall include also any potential losses or actual or potential benefits that might be calculated, provided that such damages resulted from the act or omission of the person causing it, subject to the discretion of the trial judge. (Articles 256, 266, 268 and 272 of The Jordanian Civil Code No.43 of the year 1976).

In the Jordanian law, tort liability is normally predicated on a finding of fault, damage, and causation. Indeed, there are three conditions for injurious responsibility in the Jordanian law. First, there should be fault caused by act or omission by the wrongdoer. (Ibid. Articles 361).

In the context of unfair competition, any practice that results in detrimental effects on a trader would be qualified 
as a fault. Normally, the wrongdoer and the injured would be traders competing in the same or similar line of business. It is not necessary though that the wrongdoer should actually practicing trade. In some cases, unfair competition might be conducted by persons who are about to enter the market and they use dishonest practices to attract customers in the future.

Second, there should be material or immaterial damages caused to the injured by the wrongdoer. (Ibid. Article 362).

Apparently, the right to damages shall include moral damage. In the context of unfair competition, any trespass on a trader's honor, reputation, social status or financial standing shall render the person who commits the trespass liable for damages. Evidently, such trespass will inevitably affect the trader's business. As a result, traders should give due respect to all other competitors whatever their race, nationality, gender, age, sexual orientation or religious belief. The right to damages shall include also any potential commercial deals that has been lost by a trader due to the claimant's allegations.

And third, there should be causative relationship between the fault and the injury whereby the proof of such relationship is the responsibility of the claimant. (Ibid. Article 363).

If the defendant proves that the damage resulted from an extraneous cause with which he had nothing to do like the act of god, sudden accident, force majeure, acts of others, or the act of the person injured, he shall not be liable for damages. (Ibid. Article 261).

It must be pointed out that in the absence of definite statutory provisions defining the boundaries and limitations in relation to competition in the field of trade, it is not possible to derive clear conclusions about the precise applicability of tort liability provisions of fault, damage, and causation in the area of unfair competition. For example, in marked contrast with rules and principles of tort law and injurious acts, particularly, the establishment of causative relationship between the fault and the injury, unfait competition action might be based on preventive measure to encounter futural possible infringements, if the plaintiff proves that the competition is about to take place, and may cause great damage that is hard to be redressed. (See Article 3(c)(1) of JUCL). In fact, rules and principles of tort law and injurious acts aim merely at compensating the injured while unfair competition action exceeds compensation to precautionary impoundment of the related articles and goods (Fiki 2002). In this regard, Article 3(b) of JUCL states that:

upon filing a civil lawsuit related to unfair competition or during the examination of such lawsuit, any interested party may submit an application to the relevant court accompanied by bank or cash security accepted by the court for adopting the following measures: 1. Stopping such competition. 2. Precautionary Impoundment of the related articles and goods wherever it was. 3. Reserving the related evidences. (See Article 3(b) of JUCL).

In addition, in preventive measures, Article 32 of the Jordanian Law of Civil Procedures granted the Judge the discretion to deal with preventive measures in an expedited manner without the need to summon disputants unless the court decides otherwise. (Article 32 of the Jordanian Law of
Civil Procedures No. 26 of the year 2002. The law has been published in the Jordanian Official Gazette No. 4547 dated $16 / 5 / 2002$ at p.2066).

However, Article 141 of the same law states that in order to apply preventive measures, there should be clear determination of the amount of the due debt under consideration. Apparently, the deployment of this condition in an unfair competition action is not feasible since determining upon actual or potential damages is a complicated issue. For example, drawing away customers, as a proof of damages, can be attributed to factors other than unfair competition. Accordingly, judges in Jordan are bound to understand the peculiar technical-legal nature of unfair competition whereby using deceptive practices to distract customers from a certain trader, by whatever mean, and where bad faith is a presumptive issue, is sufficient to establish legal grounds to for an unfair competition action.

\section{CONCLUSION}

Establishing an efficient unfair competition regime is capable of increasing confidence among foreign investors and businesses and achieves sustained growth. Therefore, it is a key for investment (Ma'ayeh 2001). From this perspective, one should applaud Jordan for undertaking the initiative of establishing an unfair competition regime. However, it must be pointed out that it could prove difficult to establish a correlation between strong unfair competition regime in Jordan and increase investment. The problem is lack of data and empirical studies in Jordan. Possible solution is to survey investors in Jordan. Having said that, a possible problem faces conducting empirical studies and surveys in Jordan for investigating the correlation of increase investment and strong unfair competition regime is how to neutralize other factors associated with investment in Jordan such as lower costs of production, cheap labor, and the political upheaval in the Middle East (Malkawi 2008).

Presently, the Jordanian legal system provides only very limited protection which is not adequate to accommodate unfair competition cases. Therefore, statutory changes are needed. For example, compliance with the law might be ensured by making infringements of the court order in this respect a criminal offence where fines can be imposed. In this regard, it is possible to impose a periodic penalty payment for every day the order is not respected.

Bearing in mind that legal amendments would be more successful, if there has been an educational program in the field of unfair competition protection, either at a governmental or non-governmental level, in order to reduce constraints resulted from cultural and educational gap. Effective protection of unfair competition will inevitably be enhanced by establishing educational programs in Jordan. For example, there should be investment in educating members of the bar, judges, prosecutors, and the public on the scope of unfair competition protection in order to stimulate compliance. Judges in particular are bound to understand the peculiar technical-legal nature of unfair competition whereby using deceptive practices to distract customers from a certain trader, by whatever mean, and where bad faith is a presumptive issue, is sufficient to establish legal grounds to for an unfair competition action. By the same token, a claimant in an unfair competition case, should be able to consult with 
experienced lawyers and make a careful balance of the advantages and disadvantages of available remedies under the current Jordanian legal system.

This should be a good starting point for developing case law in Jordan where the legal protection of unfair competition is not yet firmly established. In this way, unfair competition case law can be established gradually and cumulatively on a case by case basis. In particular, Jordanian courts must now look to a crucial factor which must be addressed if the Jordanian unfair competition framework is to be truly strengthened: deterrence. Jordanian courts must recognize the deterrent function of large damage awards and the potential effect that such awards may have on the enforcement of unfair competition regime in Jordan. Indeed, the willingness of courts to recognize infringement through a more expansive reading of the existing damages provisions in tort law and to grant larger damage awards can effectuate stronger unfair competition regime in Jordan.

\section{REFERENCES}

Abu-Awad, M. (2007) Civil Protection of Unregistered Trademarks in Jordan: A Comparative Study with Arab Countries. Amman, Jordan: University Publication Ltd.

Arene, M. \& Mohammed, J. (1998). Commercial Law in Arab Countries. Cairo, Egypt: University Publications Ltd.

Arkin, S. (2005). The Unfair Competition Law After Proposition 64: Changing The Consumer Protection Landscape. Western State University Law Review 32, 162.

Aukaili, A. (2007). Commercial Law in Jordan. Amman, Jordan: Dar-AlThaqafa Publications Ltd.

Callman, R. (1994). The Law of Unfair Competition, Trademarks and Monopolies. United States: Callaghan \& Company.

Carlos, A. \& Carsten, F. (1998). The Relationship between Intellectual Property and Foreign Direct Investment. Duke Journal of Comparative and International Law 9, 163-167.

Carroll, J. (2001). Intellectual Property Rights in the Middle East: A Cultural Perspective, Fordham Intellectual Property. Media and Entertainment Law Journal 11, 555-558.

Carter, S. (1990). The Trouble with Trademarks. Yale Law Journal 99, 764.

Fiqi, A. (2002). Protection of Trade Names in Arab Countries: A Comparative Study. Cairo, Egypt: Dar Al-Nahda Publication Ltd.

Malkawi, B. (2008). Jordan and the World Trading Systems: A Case Study For Arab Countries. Germany: VDM Verlag.

Muhriz, A. (1994). Protection of Competition in Jordan. Amman, Jordan: Dar Al-Thakafa Publication Ltd.

Qaid, M. (2001). Commercial Law In Arab Countries. Cairo, Egypt: Dar AlNahda Publication Ltd.
Qalioubi, S. (2005). Commercial Law In Arab Countries. Cairo, Egypy: Dar Al-Nahda Publication Ltd.

Samaha, J. (1991) Unfair Competition in Jordan. Beirut, Lebanon: Dar AlThakafa Publication Ltd.

Sanhuri, A. (1952). The theory of Obligation in Arab Countries. Cairo, Egypt: Dar Al-Nahda Publication Ltd.

Denham, W. (2001). No More than Lanham, No Less than Paris?: A Federal Law of Unfair Competition. Texas International Law Journal 36, 801.

Deutch, M. (2004). Unfair Competition and the "Misappropriation Doctrine": A Renewed Analysis. Saint Louis University Law Journal $48,503$.

Haines, C. (1919). Efforts to Define Unfair Competition. Yale Law Journal $29,13$.

Knight, V. (1978). Selected Business Torts in Civil and Common Law Systems: Unfair Competition: A Comparative Study of its Role in Common and Civil Law Systems. Tulane Law Journal 53, 164.

Melhem, A. (1995). Agreements on Restriction of Prices: Effects on Competition. Kuwait Law Review 19, 38.

Rotondi, A. (1958). Unfair Competition in Europe. American Journal of Comparative Law 7, 331.

Saleh, N. (1999). Consumer Protection Under the Jordanian Law. Kuwait Law Review 23, 141

Sease, E. (1994). Misappropriation is Seventy-Five Years Old: Should We Bury It or Revive It?. North Dakota Law Review 70, 805.

Torem, N. \& Goldstein, S. (1972). Denigration and Disparagement: A Franco American Comparative Analysis. Texas Intellectual Property Law Journal 7, 213.

Paris Convention for the Protection of Industrial Property of the year 1883 and its amendments.

The Jordanian Unfair Competition Law No. 15 of the year 2000.

The Jordanian Antitrust Law No. 49 of the year 2002.

The Jordanian Trademarks Law No.33 of the year 1999 and its amendments.

The Jordanian Commercial Code No. 12 of the year 1966.

The Jordanian Bar Association Law No. 51 of the year 1985.

The Jordanian Medical Council Law No. 81 of the year 1972.

The Jordanian Patent Law No.32 of the year 1999 and its amendments.

The Jordanian Companies Law No. 22 of the year 1997 and its amendments. The Jordanian Civil Code No.43 of the year 1976

The Jordanian Employment Law No. 60 of the year 2002.

The Jordanian Penal Law No. 33 of the Year 2002.

The Jordanian Law of Civil Procedures No. 26 of the year 2002.

The Jordanian Court of Cessation, Case No.112/24, Journal of Jordanian Bar Association 2431 (2004).

The Jordanian Court of Cessation, Case No.21/88, Journal of Jordanian Bar Association 2552 (2007).

Hanns, U. (2005). Anti-Unfair Competition Law and Anti-Trust Law: A Continental Conundrum. Retrieved November 1, 2008, from http://papers.ssrn.com/sol3/papers.cfm?abstract_id=837086

Ma'ayeh, S. (2001). Improved Intellectual Property Rights Enforcement Gets Mixed Reviews, Jordan Times, May 1, 2001.

Received: November 25, 2008

Revised: January 16, 2009

Accepted: February 2, 2009

(C) Haitham A. Haloush; Licensee Bentham Open.

This is an open access article licensed under the terms of the Creative Commons Attribution Non-Commercial License (http://creativecommons.org/licenses/by$\mathrm{nc} / 3.0 /$ ) which permits unrestricted, non-commercial use, distribution and reproduction in any medium, provided the work is properly cited. 